\title{
A novel RP-HPLC method development and validation for determination and estimation of eluxadoline drug with its impurities
}

\author{
Srinivasarao Pakalapati ${ }^{1,2}$. Chidananda Swamy Rumalla ${ }^{1}$. Atchyut Ramakrishna Gudapati ${ }^{1}$. \\ Raghu Babu Korupolu $^{2} \cdot$ Susheela Bai Gajbhiye ${ }^{2} \cdot$ Muralidharan Kaliyaperumal $^{1}$
}

Received: 15 March 2020 / Accepted: 28 April 2020 / Published online: 8 May 2020

(c) Springer Nature Switzerland AG 2020

\begin{abstract}
A Novel, efficient and convenient reversed-phase high-performance liquid chromatography method was developed for eluxadoline (EXDL) drug in the presence of its impurities 1 and 4. Successful separation of EXDL drug from the its impurities was achieved on Prontosil ODS C18 column $(5 \mu \mathrm{m} 250 \times 4 \mathrm{~mm})$ with isocratic elution of Acetonitrile:Methanol:0.1 M Sodium acetate 40:40:20 (v/v) as a mobile phase. The Ultraviolet detection was monitored at a wavelength of $246 \mathrm{~nm}$ at flow rate $1.0 \mathrm{~mL} / \mathrm{min}$. The validation of proposed method was carried for linearity, precision, accuracy, limit of detection, limit of quantification and robustness were determined in accordance with ICH guidelines. The method has good specificity and specified impurities can be effectively separated with god resolution. The proposed method is found to have linearity in the 100-600 $\mu \mathrm{g} / \mathrm{mL}$ concentration range of EXDL with correlation coefficients of not less than 0.997 and $1-6 \mu \mathrm{g} / \mathrm{mL}$ for impurity 4 and 1 with $0.994,0.997$ correlation coefficients respectively. The compounds analyzed in the solutions are stable for at least $32 \mathrm{~h}$. The limit of detection and the limit of quantification for the analytes are $0.25 \mu \mathrm{g} / \mathrm{mL}$, $25 \mu \mathrm{g} / \mathrm{mL}$ and $0.25 \mu \mathrm{g} / \mathrm{mL}$ respectively. The method successfully estimated the drug in formulation tablet ad detected the impurities. The proposed method can be applied for quality control assay of EXDL, with the advantages of simplicity, accuracy, robustness, good selectivity, and high sensitivity.
\end{abstract}

Keywords Eluxadoline $\cdot$ Impurities $\cdot$ RP-HPLC $\cdot$ ICH guidelines

Abbreviations
$\begin{array}{ll}\text { EXDL } & \text { Eluxadoline } \\ \text { ICH } & \text { International council for harmonisation } \\ \text { LOD } & \text { Limit of detection } \\ \mathrm{LOQ} & \text { Limit of quantification } \\ \mathrm{ng} / \mathrm{mL} & \text { Nano gram per } \mathrm{mL} \\ \mu \mathrm{g} / \mathrm{mL} & \text { Micro gram per } \mathrm{mL} \\ { }^{\circ} \mathrm{C} & \text { Degrees in celsius } \\ \mathrm{Imp}-1 & \text { Impurity } 1 \\ \mathrm{Imp}-4 & \text { Impurity } 4\end{array}$

US FDA United state food and drug administration

RSD Relative standard deviation

HPLC High pressure liquid chromatography

ppm Parts per million

$\mu \mathrm{L} \quad$ Micro liter

Electronic supplementary material The online version of this article (https://doi.org/10.1007/s42452-020-2834-9) contains supplementary material, which is available to authorized users.

Srinivasarao Pakalapati, pakalapatisrinivas1980@gmail.com | ${ }^{1}$ Department of Medicinal Chemistry, GVK Biosciences Pvt. Ltd, IDA Nacharam, Hyderabad, Telangana 500076, India. ${ }^{2}$ Department of Engineering Chemistry, Andhra University, Visakhapatnam, AP 530003, India. 


\section{Introduction}

Eluxadoline (EXDL), is a mixed opioid receptor agonist (mu) and antagonist (delta) drug that is used for the treatment of diarrhea and abdominal pain in individuals with diarrhea-predominant irritable bowel syndrome (IBS-D) [1-4]. The drug is approved in 2015 in USA [1]. Exdl works by slowing down the motion in gut by $\mu$ - and $\mathrm{k}$-opioid receptor agonist activity and $\delta$-opioid receptor antagonist that acts locally in the enteric nervous system which helps minimizes symptoms such as belly pain and diarrhea [5-7]. The drug is available as oral dosage form with food. The most common adverse reactions ( $>5 \%$ ) with usage of EXDL are constipation, nausea and abdominal pain and rare adverse effects includes fatigue, bronchitis, viral gastroenteritis [8] (Fig. 1).

The present work is aimed to develop and validate a RPHPLC method for determination of EXDL and its impurity 1 and 4. Chemical formula of impurity 1 is $\mathrm{C}_{32} \mathrm{H}_{35} \mathrm{~N}_{5} \mathrm{O}_{5}$ and impurity 4 is $\mathrm{C}_{18} \mathrm{H}_{24} \mathrm{~N}_{2} \mathrm{O}_{4}$. Chemical structure of the impurity 1 and are presented Fig. 2. These are two analytical methods have been reported for EXDL. One method is formulation estimation [9] by HPLC DAD method and another method is for UPLC MS/MS estimation of EXDL in plasma [10]. Hence the present attempt is a novel approach for<smiles>COc1ccc(CN(C(=O)[C@H](N)Cc2c(C)cc(C(N)=O)cc2C)[C@@H](C)c2nc(-c3ccccc3)c[nH]2)cc1C(=O)O</smiles>

Fig. 1 Chemical structure of eluxadoline [EXDL] estimation EXDL and its impurities. Many pharmaceutical industries develop a drug impurity profile, which is defined as 'a description of the identified and unidentified impurities present in a new drug substance'. Impurities can be formed during drug synthesis, manufacturing, and/ or storage. Impurity of the drug is defined as 'any component of the new drug substance that is not the chemical entity defined as the new drug substance'. The drug impurities should be identified, qualified and/or quantified whether or not certain threshold (concentration) limits are exceeded. Impurity profile analyses are required to demonstrate the ability to detect a wide range of impurities which may occur in pharmaceuticals $[11,12]$. The chromatographic impurity profile should allow detecting and separating all (un) identified impurities in each new active compound. High performance liquid chromatography (HPLC) is routinely used for determination of both assay and impurities in both bulk active and formulated drug products.

The objective of the presently reported work was to develop and validate $[13,14]$ an HPLC test method to have in place to evaluate different synthetic lots of this drug substance. Although isocratic HPLC systems have been used often for the determination of impurities in bulk drug $[10,11]$, as well as stability indicating assays. The object of the proposed method is novel over existed liquid chromatography methods, where no such method was not described impurity analysis. The method was also intended to determine the quantity of the drug in pharmaceutical dosage forms; hence the method is applicable for formulation analysis also.

\section{Materials and methods}

\subsection{Instruments used}

Agilent 1100 series HPLC instrument with Quaternary G1311 A pump, COLCOM G1316A thermostat column temperature control, Thermostatic auto sampler $G$ $1329 \mathrm{~A}$ with sample volume of $0.1-1500 \mu \mathrm{L}$ and variable
Fig. 2 EXDL impurity 1 and impurity 4<smiles>COc1ccc(CC(C(=O)[C@H](N)Cc2c(C)cc(C(N)=O)cc2C)[C@H](C)c2ncc(-c3ccccc3)[nH]2)cc1C(=O)O</smiles><smiles>COC(=O)[C@H](Cc1c(C)cc(C#N)cc1C)NC(=O)OC(C)(C)C</smiles> 
programmable UV detector G $1314 \mathrm{~A}$. The instrument was operated and integrated with Agilent chem. station LC software.

\subsection{Chemicals used}

High-purity HPLC grade water, acetonitrile and methanol are purchased from Thermo Fisher Scientific India private limited, Mumbai, India. LR grade Sodium acetate from Thermo fisher Scientific India private limited, Mumbai.

\subsection{Preparation of standard drug and impurity solutions}

Accurately weighed $10 \mathrm{mg}$ of EXDL was transferred to a $10 \mathrm{~mL}$ volumetric flask, added about $5 \mathrm{~mL}$ of methanol and sonicated to dissolve, diluted up to the mark with methanol. This is kept as $1000 \mu \mathrm{g} / \mathrm{mL}$ standard stock solution. Standard calibration solutions were prepared from stcok solution.

\subsection{Preparation of Impurity solutions}

Further RR Isomer EXDL i.e. impurity 1 and impurity 4 also prepared as same procedure. Accurately weighed $10 \mathrm{mg}$ of EXDL impurity 1 and 4 were transferred to a $10 \mathrm{~mL}$ volumetric flask, added about $5 \mathrm{~mL}$ of methanol and sonicated to dissolve, diluted up to the mark with methanol. From the above solution $1 \mathrm{~mL}$ of solution is pipette out into a $10 \mathrm{~mL}$ volumetric flask and volume was made up to mark with methanol to get $100 \mu \mathrm{g} / \mathrm{mL}$ of Impurities in solution. From $100 \mu \mathrm{g} / \mathrm{mL}$ impurity solution again diluted to obtain desired concentrations. Mixture solutions of standard EXDL and impurity are prepared by mixing the appropriate concentration.

\subsection{Preparation of Sample solution}

The tablet formulation of EXDL drug VIBERZI with $100 \mathrm{mg}$ was purchased for local pharmacy. Total ten tablets were weighed and powdered into fine and tablet powder equivalent to $10 \mathrm{mg}$ of EXDL was weighed and transferred to $10 \mathrm{~mL}$ of volumetric flask and dissolved in Diluents. The flask was shaken and volume was made up to mark with diluent solution concentration is $1.0 \mathrm{mg} / \mathrm{mL}$. From above stock solution $200 \mu \mathrm{g} / \mathrm{mL}$ of sample concentration was prepared by diluting with methanol for estimation.

\subsection{Method development and validation}

The development of method conditions are intended for separation of parent EXDL drug with its impurities 1 and 4. Initially major separating objects of HPLC were optimized to initiate the separation. Methanol, water and acetonitrile solvents were optimized with different ratio as eluent were studied. Though the various columns like $\mathrm{C} 8, \mathrm{C} 18$ columns with different lengths were studied for development, resolution of the drug and its impurities peaks was acceptable with $\mathrm{C} 18$ column. Resolution between drug and its impurities was consistently greater than 6.0. This was more than adequate resolution for separation. The $\mathrm{pH}$ and concentration of $0.1 \mathrm{M}$ Sodium acetate were optimized for the best peak shape and best theoretical plate count for this chromatographic procedure. The separation of the two impurity analytes (Impurity 1 and 4) from the parent EXDL were accomplished using proposed chromatographic procedure.

A solution containing $100 \mu \mathrm{g} / \mathrm{mL}$ of EXDL standard concentration and $1 \mu \mathrm{g} / \mathrm{mL}$ impurity 1 and 6 concentrations are prepared from the diluting from stock solutions of respective compounds.

The linearity at different concentrations was assessed covering an approximate range of (LOQ level to $100 \mu \mathrm{g} /$ $\mathrm{mL}$ ) at six different concentration levels. Graphs of peak area against concentration were plotted for EXDL and each of the impurities using a linear regression model. Mixed standard solutions of $200 \mu \mathrm{g} / \mathrm{mL}$ of EXDL and $2 \mu \mathrm{g} / \mathrm{mL}$ each of the impurities I and 4 were prepared for other validation studies like precision, ruggedness and robustness studies. The precision of the method was studied by intraday and interday analysis of repeatability test by injecting six times of the standard solution at the same day and between 3 days of intervals. Ruggedness was evaluated by injecting the standard solution six times by varying the analyst. Percentage of RSD was calculated for peak areas obtained for all peaks. Robustness of the method was evaluated by slight modification of proposed method parameters like Ultraviolet detector wavelength (245 and $247 \mathrm{~nm}$ ), mobile phase composition (38:42:20 and 42:38:20 (v/v) of Acetonitrile:Methanol:0.1 M Sodium acetate) and flow rate $(0.9$ and $1.1 \mathrm{~mL} / \mathrm{min})$ of the mobile phase. Limit of detection (LOD) was determined from visual observation of areas and system suitability conditions of peak. Limit of quantization (LOQ) is found the lowest concentrations of calibration curve. The accuracy of method was established by recovery studies by spiking the $50 \%$, $100 \%$ and $150 \%$ of mixed standard solutions of $200 \mu \mathrm{g} /$ $\mathrm{mL}$ of EXDL and $2 \mu \mathrm{g} / \mathrm{mL}$ concentrations each of the impurities. The recovery analysis for each level was carried out in triplicate. The tablet formulation of EXDL drug 
VIBERZI was analyzed by triplicate analysis of the sample solution equal to the $200 \mu \mathrm{g} / \mathrm{mL}$ of EXDL and $2 \mu \mathrm{g} / \mathrm{mL}$ concentrations.

\subsection{Study of solution stability}

To determine the stability of sample solution, the sample solutions of EXDL spiked with impurities at specified level were prepared and analyzed immediately after preparation. The prepared sample solution was analyzed after different time intervals up to $24 \mathrm{~h}$, while stored by maintaining the sample cooler temperature at about $25^{\circ} \mathrm{C}$.

\section{Results and discussion}

\subsection{Development of chromatographic system}

The chromatographic separation was achieved on an Agilent 1100 series HPLC instrument with Prontosil ODS C18 column $(5 \mu \mathrm{m} 250 \times 4 \mathrm{~mm})$. The isocratic LC method employs mobile phase mixture of Acetonitrile:Methanol:0.1 M Sodium acetate 40:40:20 $(\mathrm{v} / \mathrm{v})$. The flow rate of the mobile phase was $1.0 \mathrm{~mL} / \mathrm{min}$ and Ultraviolet detection was monitored at a wavelength of $246 \mathrm{~nm}$. The C 18 column is successfully separated and identified the three compounds. And the best resolution was achieved by using the $\mathrm{C} 18$ column with $250 \mathrm{~mm}$ length, where more than 6 resolutions were achieved with specificity. The HPLC isocratic elution completed at below
12 min with run time was $20 \mathrm{~min}$. The column temperature was maintained at ambient temperature with injection volume was $20 \mu \mathrm{L}$. Two possible impurities were of concern in this study. The RR Isomer impurity 1 and impurity 4 (Fig. 2) of the EXDL parent compound were included in the validation work of this test procedure. The recovery data and other validation results of this study will be discussed. The developed method conditions are presented in the Table 1. The validation of proposed method was carried for linearity, precision, accuracy, limit of detection (LOD), limit of quantification (LOQ) and robustness were determined in accordance with $\mathrm{ICH}$ guidelines.

\subsection{Method validation}

Specificity of a HPLC method is the ability to measure the analyte response in the presence of its potential impurities. The specificity of the proposed method was carried out in the presence of its impurities namely, Impurity 1 and impurity 4. The standard concentrations of EXDL, impurity 1 and 4 are injected individually to determine the retention time and also verified against the blank injection. There is no additional peaks were observed. The retention time was found 6.11, 9.43 and $11.63 \mathrm{~min}$ for impurity 4, EXDL and impurity 1 respectively. Chromatogram of the standard mixture solution was presented in Figs. 3 and 4 . The chromatogram meets all the system suitability conditions like Theoretical Plates and tailing factors etc. very high resolution was found between both impurity 4 and drug as well as drug and impurity 1 . Even though

Table 1 Optimized chromatography conditions

\begin{tabular}{|c|c|c|c|}
\hline S. no. & Chromatographic condition & Results & Conclusion \\
\hline 1 & $\begin{array}{l}\text { MP: Acetonitrile:Methanol 80:20 (v/v) } \\
\text { column: C8 }(5 \mu \mathrm{m} 150 \times 4 \mathrm{~mm}) \\
\text { detector wavelength: } 248 \mathrm{~nm}\end{array}$ & $\begin{array}{l}\text { EXDL and impurities were identified with merged peaks } \\
\text { fail to pass system suitable condition }\end{array}$ & Method rejected. \\
\hline 2 & $\begin{array}{l}\text { MP: Acetonitrile:Methanol 60:40 (v/v) } \\
\text { column: C8 }(5 \mu \mathrm{m} 150 \times 4 \mathrm{~mm}) \\
\text { detector wavelength: } 248 \mathrm{~nm}\end{array}$ & $\begin{array}{l}\text { EXDL and impurities were identified with merged peaks } \\
\text { fail to pass system suitable conditions }\end{array}$ & Method rejected \\
\hline 3 & $\begin{array}{l}\text { MP: Acetonitrile:Methanol 50:50 (v/v) } \\
\text { column: C8 }(5 \mu \mathrm{m} 150 \times 4 \mathrm{~mm}) \\
\text { detector wavelength: } 248 \mathrm{~nm}\end{array}$ & $\begin{array}{l}\text { EXDL and impurities were identified but peaks are } \\
\text { failed to separate with good resolution }\end{array}$ & Method rejected \\
\hline 4 & $\begin{array}{l}\text { MP: Acetonitrile:Acetonitrile:Methanol: } 0.1 \text { M sodium } \\
\text { acetate } 40: 40: 10(\mathrm{v} / \mathrm{v}) \\
\text { column: } \mathrm{C} 8(5 \mu \mathrm{m} 150 \times 4 \mathrm{~mm}) \\
\text { detector wavelength: } 248 \mathrm{~nm}\end{array}$ & $\begin{array}{l}\text { EXDL and impurities were identified. Sharp peaks with } \\
\text { system suitable conditions were obtained. But peaks } \\
\text { are failed to separate with good resolution }\end{array}$ & Method rejected \\
\hline 5 & $\begin{array}{l}\text { MP: Acetonitrile:Acetonitrile:Methanol:0.1 M sodium } \\
\text { acetate } 40: 40: 10(\mathrm{v} / \mathrm{v}) \\
\text { column: } \mathrm{C} 8(5 \mu \mathrm{m} 250 \times 4 \mathrm{~mm}) \\
\text { detector wavelength: } 248 \mathrm{~nm}\end{array}$ & $\begin{array}{l}\text { EXDL and impurities were identified. Peaks are separate } \\
\text { with good resolution }\end{array}$ & Method rejected \\
\hline 6 & $\begin{array}{l}\text { MP: Acetonitrile:Acetonitrile:Methanol:0.1 M Sodium } \\
\text { acetate } 40: 40: 20(\mathrm{v} / \mathrm{v}) \\
\text { column: } \mathrm{C} 8(5 \mu \mathrm{m} 250 \times 4 \mathrm{~mm}) \\
\text { detector wavelength: } 248 \mathrm{~nm}\end{array}$ & $\begin{array}{l}\text { EXDL and impurities were identified. Sharp peaks with } \\
\text { system suitable conditions were obtained. Peaks are } \\
\text { separate with good resolution }\end{array}$ & $\begin{array}{l}\text { Method finalized } \\
\text { for validation }\end{array}$ \\
\hline
\end{tabular}


Fig. 3 System suitability chromatogram of proposed method separating impurity 4 , EXDL and impurity 1
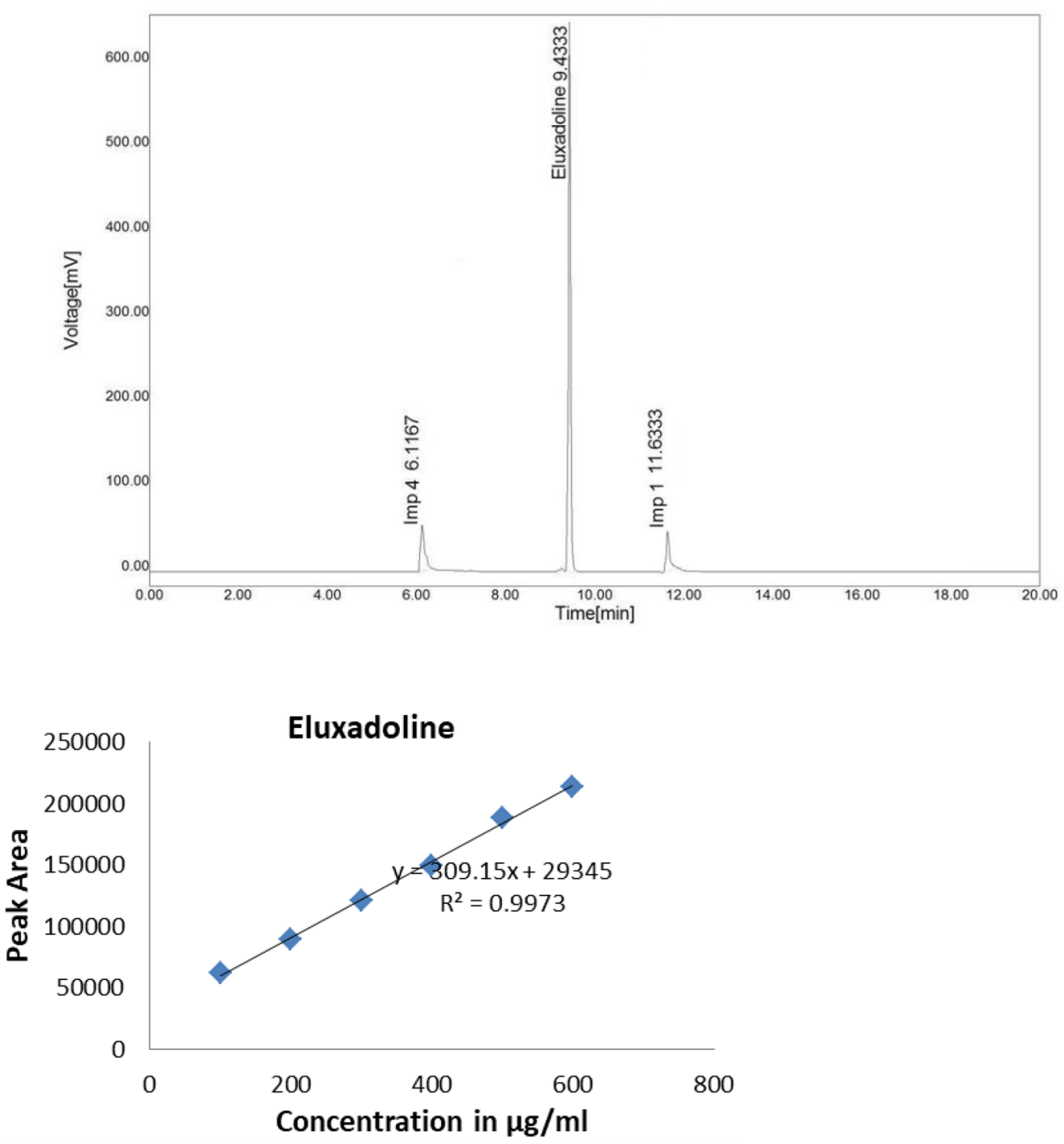

Impurity 1

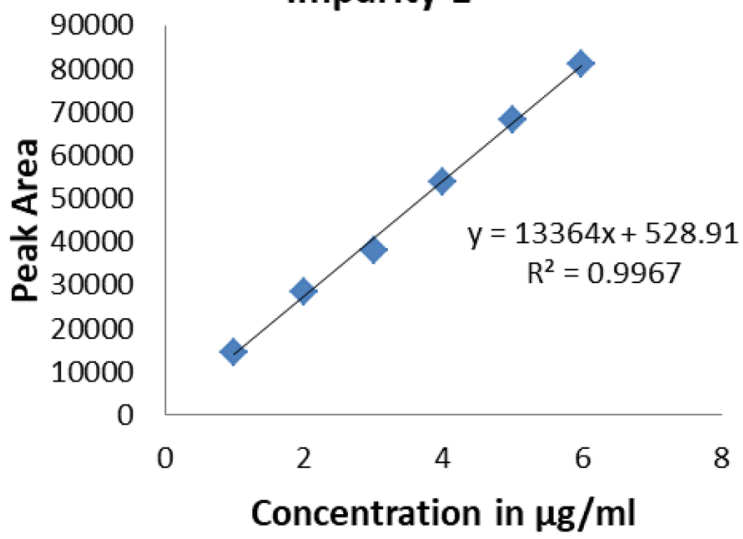

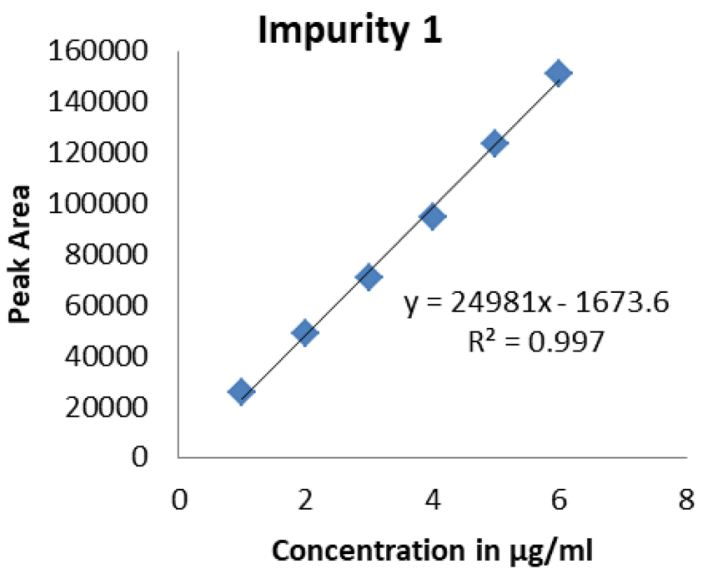

Fig. 4 Calibration graph of EXDL, impurity 1 and impurity 4 
Table 2 Results of calibration (linearity) study

\begin{tabular}{|c|c|c|c|c|c|c|}
\hline \multirow[t]{2}{*}{ S. no. } & \multicolumn{2}{|l|}{ Impurity 4} & \multicolumn{2}{|l|}{ EXDL } & \multicolumn{2}{|l|}{ Impurity 1} \\
\hline & $\begin{array}{l}\text { Concentration } \\
\text { in } \mu \mathrm{g} / \mathrm{mL}\end{array}$ & peak area & $\begin{array}{l}\text { Concentration } \\
\text { in } \mu \mathrm{g} / \mathrm{mL}\end{array}$ & Peak area & $\begin{array}{l}\text { Concentration } \\
\text { in } \mu \mathrm{g} / \mathrm{mL}\end{array}$ & Peak area \\
\hline 1 & 1 & 14552.3 & 100 & 62547.3 & 1 & 25779.6 \\
\hline 2 & 2 & 28477.1 & 200 & 89566.3 & 2 & 48665.6 \\
\hline 3 & 3 & 37884.9 & 300 & 121247 & 3 & 71004.6 \\
\hline 4 & 4 & 53669.4 & 400 & 149361 & 4 & 94771.6 \\
\hline 5 & 5 & 67994.5 & 500 & 188725 & 5 & 123117 \\
\hline 6 & 6 & 81229.8 & 600 & 213833 & 6 & 151223 \\
\hline Slope & & 13364 & & 309.15 & & 24981 \\
\hline Intercept & & 528.91 & & 29345 & & 1673.6 \\
\hline $\begin{array}{l}\text { Correlation } \\
\text { coefficient }\end{array}$ & & 0.996 & & 0.997 & & 0.997 \\
\hline
\end{tabular}
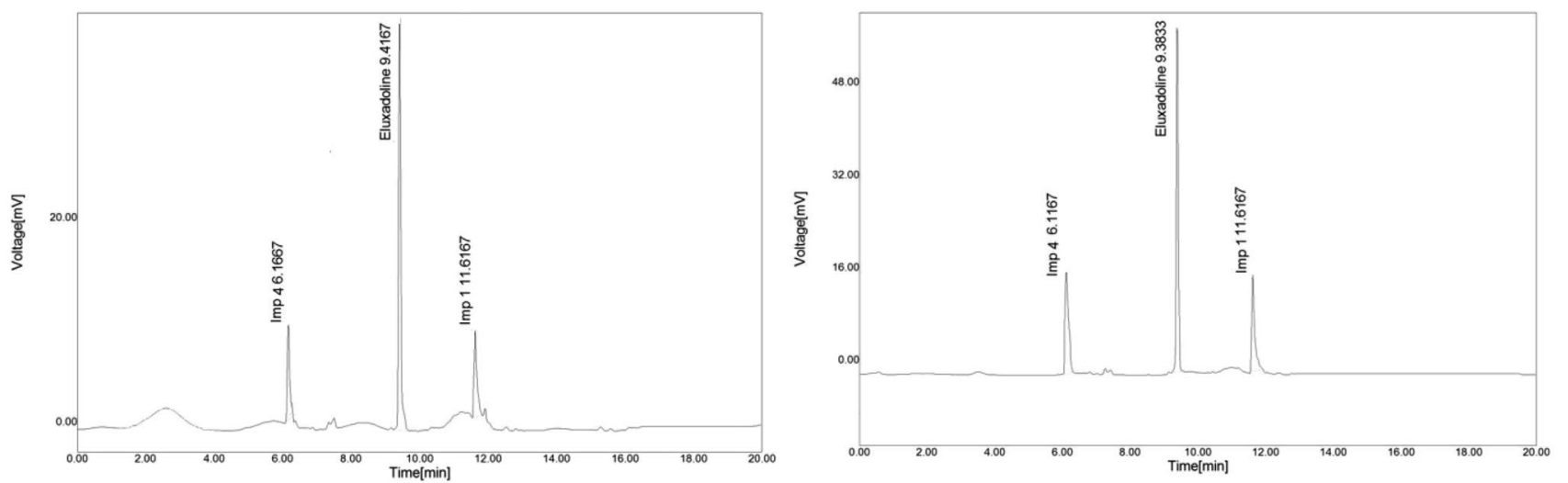

Fig. 5 Chromatogram of limit of detection and limit of quantification

the response of the both impurities are were found high, concentration of impurities were taken as lower range to evaluate natural concentration range.

Linearity of response for the EXDL as well as impurity 1 and 4 was also verified during this work. Chromatographed solutions having concentrations of $100-600 \mu \mathrm{g} /$ $\mathrm{mL}$ for EXDL and 1-6 $\mu \mathrm{g} / \mathrm{mL}$ for both impurities gave peak area responses that were linear and the correlation coefficient was $\left(R^{2}\right)$ 0.997. Results of linearity study were presented in Table 2 and calibration curve of the EXDL and impurity 1 and 4 are presented in Fig. 4 . The precision of the method was checked by injecting six individual preparations of EXDL $(200 \mu \mathrm{g} / \mathrm{mL})$ spiked with Imp-1 and Imp-4 $(6 \mu \mathrm{g} / \mathrm{mL})$. The \% RSD of the area for drug and each impurity was calculated. The intermediate precision of the method was also evaluated using different analyst and different instrument in the same laboratory (Fig. 5).

Intraday precision percentage RSD for impurity 4, EXDL and impurity 1 respectively were found 1.63, 0.82 and 1.66 respectively (Table 3 ). For interday precision percentage RSD for impurity 4, EXDL and impurity 1
Table 3 Results of intraday precision

\begin{tabular}{lccc}
\hline S. no. & \multicolumn{3}{l}{ Peak area $\%$} \\
\cline { 2 - 4 } & $\begin{array}{lll}\text { Impurity 4 }(2 \mu \mathrm{g} / \\
\mathrm{mL})\end{array}$ & $\begin{array}{l}\text { Eluxadoline } \\
(200 \mu \mathrm{g} / \mathrm{mL})\end{array}$ & $\begin{array}{c}\text { Impurity 1 } \\
(2 \mu \mathrm{g} / \mathrm{mL})\end{array}$ \\
\hline 1 & 99.89 & 98.38 & 98.79 \\
2 & 100.04 & 100.87 & 101.16 \\
3 & 98.93 & 99.74 & 99.55 \\
4 & 98.29 & 99.24 & 98.99 \\
5 & 99.90 & 99.86 & 99.86 \\
6 & 100.08 & 99.63 & 100.30 \\
\hline
\end{tabular}

respectively were found $1.98,0.97$ and 1.44 respectively (Table 4). Hence the result proves the effective repeatability. The reproducibility (Ruggedness) of this test procedure was demonstrated by analyzing the same lot of drug using two different chemists in different days and RSD was calculated. Percentage RSD for impurity 4, EXDL and impurity 1 respectively were found 1.80, 0.90 and 1.94 respectively (Table 5 ). Results of repeatability 
Table 4 Results of interday precision

\begin{tabular}{lllc}
\hline S. no & \multicolumn{3}{l}{ Peak area $\%$} \\
\cline { 2 - 4 } & $\begin{array}{l}\text { Impurity 4 }(2 \mu \mathrm{g} / \\
\mathrm{mL})\end{array}$ & $\begin{array}{l}\text { Eluxadoline } \\
(200 \mu \mathrm{g} / \mathrm{mL})\end{array}$ & $\begin{array}{c}\text { Impurity 1 } \\
(2 \mu \mathrm{g} / \mathrm{mL})\end{array}$ \\
\hline 1 & 100.07 & 99.21 & 99.64 \\
2 & 98.95 & 100.31 & 99.60 \\
3 & 99.22 & 101.26 & 99.37 \\
4 & 99.54 & 101.35 & 101.81 \\
5 & 98.79 & 99.16 & 98.53 \\
6 & 98.67 & 99.75 & 101.44 \\
\hline
\end{tabular}

Table 5 Results of ruggedness

\begin{tabular}{llll}
\hline S. no. & \multicolumn{3}{l}{ Peak area obtained } \\
\cline { 2 - 4 } & $\begin{array}{l}\text { Impurity } 4(2 \mu \mathrm{g} / \\
\mathrm{mL})\end{array}$ & $\begin{array}{l}\text { Eluxadoline } \\
(200 \mu \mathrm{g} / \mathrm{mL})\end{array}$ & $\begin{array}{l}\text { Impurity } \\
1(2 \mu \mathrm{g} / \\
\mathrm{mL})\end{array}$ \\
\hline 1 & 28269.6 & 88997.4 & 48117.3 \\
2 & 28511 & 89639.5 & 48125.6 \\
3 & 27987.1 & 91014.5 & 47377.7 \\
4 & 27557.3 & 89336.1 & 47548.9 \\
5 & 28238.4 & 89593 & 49880.9 \\
6 & 29075.5 & 88694.6 & 48943 \\
$\%$ RSD & 1.80 & 0.90 & 1.94 \\
\hline
\end{tabular}

Table 6 Summery of validation results

\begin{tabular}{|c|c|c|c|}
\hline Parameter & Impurity 4 & EXDL & Impurity 1 \\
\hline RT & $6.1167 \mathrm{~min}$ & $9.433 \mathrm{~min}$ & $11.6333 \mathrm{~min}$ \\
\hline Resolution & - & 16.20 & 12.18 \\
\hline Theoretical plates & 6024 & 14256 & 5225 \\
\hline Tailing factor & 0.91 & 1.28 & 1.15 \\
\hline $\begin{array}{l}\text { Intraday precision } \\
\text { (\%RSD) }\end{array}$ & 1.63 & 0.82 & 1.66 \\
\hline $\begin{array}{l}\text { Interday precision } \\
\text { (\%RSD) }\end{array}$ & 1.98 & 0.97 & 1.44 \\
\hline Ruggedness (\%RSD) & 1.80 & 0.90 & 1.94 \\
\hline Robustness (\% assay) & 98.07-101.84 & $98.28-100.35$ & $99.7-101.1$ \\
\hline Recovery (\% assay) & 98.51-101.36 & $99.02-101.23$ & 98.23-101.09 \\
\hline LOQ & $1 \mu \mathrm{g} / \mathrm{mL}$ & $100 \mu \mathrm{g} / \mathrm{mL}$ & $1 \mu \mathrm{g} / \mathrm{mL}$ \\
\hline LOD & $250 \mathrm{ng} / \mathrm{mL}$ & $25 \mu \mathrm{g} / \mathrm{mL}$ & $250 \mathrm{ng} / \mathrm{mL}$ \\
\hline
\end{tabular}

studies were presented in the summery of validation Table 6.

The accuracy of proposed HPLC method to evaluate the level of known impurities was verified by chromatographing solutions containing known levels of the two analog compounds. To the EXDL $(200 \mu \mathrm{g} / \mathrm{mL})$ spiked with Imp-1 and Imp-4 (6 $\mathrm{gg} / \mathrm{mL})$ concentration spike levels of $50 \%, 100 \%$ and $150 \%$ were studied for recovery study (Table 7). Percent recovery, for impurity 4, EXDL and impurity 1 respectively were found between 98.51-101.36, 99.02-101.23 and 98.23-101.09 respectively (Tables 6 and 7). There are no significant changes were observed when modification was done on for robustness study (Table 8 ). Hence it proves the robustness of the method. The calculated instrumental limit of detection (LOD) was determined by injecting diluted concentration of standard solution that is failing the system suitable conditions. The instrumental LOD of the proposed method for impurity 4, EXDL and impurity 1 respectively were found $0.25 \mathrm{ng} / \mathrm{mL}, 25 \mu \mathrm{g} / \mathrm{mL}$ and $0.25 \mathrm{ng} / \mathrm{mL}$ respectively (Table 6 ). Hence the proposed method can be detecting the EXDL drug impurities even in very less concentration range. The robustness (i.e., its characteristic to remain unaffected by small changes) of proposed method was verified by slight changes in the method conditions like detector wavelength, $\mathrm{pH}$ of the mobile phase and mobile phase ratio. There was no significant difference in the drug as well as impurity levels estimated after the studies. The advantages of the proposed methods over repored liquid chromatography methods are presented in the Table 9.

\subsection{Stability of the solution}

To assess the stability of the drug substance dissolved in methanol was established. A sample solution held at refrigerator at $15^{\circ} \mathrm{C}$ for $48 \mathrm{~h}$ did not show any appreciable increase or change in impurity peaks; therefore, the sample solution appears to be reasonably stable upon short-term standing. This was more than an adequate time interval to perform an analysis and not be concerned with the possibility of degradation during analysis, which would bias results. Assay results of the standard mixture solutions at each time point were analyzed and compared with the calibrated results. The results from these studies indicated, the sample solution was stable at room temperature for at least $32 \mathrm{~h}$.

\subsection{Samples assay}

Commercial sample of EXDL drug (VIBERZI-100 mg) were analyzed to estimate the drug in tablet formulation with $100.10 \%$ of assay as well as to determine the impurities. The method successfully detected the impurity 1 and 4 in the formulation. There was no unspecified impurity interfering with drug, indicating that the method can be used for the determination for EXDL drug and its impurity 1 and 4. 
Table 7 Results of recovery studies

\begin{tabular}{|c|c|c|c|c|c|c|}
\hline \multirow[t]{2}{*}{ S. no. } & \multicolumn{5}{|c|}{ Concentration in $\mu \mathrm{g} / \mathrm{mL}$} & \multirow[t]{2}{*}{$\%$ Recovery } \\
\hline & Level & Target & Spiked & Total & Recovered & \\
\hline \multicolumn{7}{|c|}{ Impurity 4} \\
\hline 1 & $50 \% 1$ & 2 & 1 & 3 & 2.98 & 99.38 \\
\hline 2 & $50 \% 2$ & 2 & 1 & 3 & 3.01 & 100.25 \\
\hline 3 & $50 \% 3$ & 2 & 1 & 3 & 3.01 & 100.01 \\
\hline 4 & $100 \% 1$ & 2 & 2 & 4 & 4.02 & 100.62 \\
\hline 5 & $100 \% 2$ & 2 & 2 & 4 & 4.05 & 101.24 \\
\hline 6 & $100 \% 3$ & 2 & 2 & 4 & 4.05 & 101.36 \\
\hline 7 & $150 \% 1$ & 2 & 3 & 5 & 4.92 & 98.51 \\
\hline 8 & $150 \% 2$ & 2 & 3 & 5 & 4.93 & 98.60 \\
\hline 9 & $150 \% 3$ & 2 & 3 & 5 & 5.03 & 100.68 \\
\hline \multicolumn{7}{|c|}{ Eluxadoline } \\
\hline 1 & $50 \% 1$ & 200 & 100 & 300 & 301.97 & 100.66 \\
\hline 2 & $50 \% 2$ & 200 & 100 & 300 & 303.71 & 101.23 \\
\hline 3 & $50 \% 3$ & 200 & 100 & 300 & 299.52 & 99.84 \\
\hline 4 & $100 \% 1$ & 200 & 200 & 400 & 398.08 & 99.52 \\
\hline 5 & $100 \% 2$ & 200 & 200 & 400 & 399.72 & 99.93 \\
\hline 6 & $100 \% 3$ & 200 & 200 & 400 & 396.37 & 99.09 \\
\hline 7 & $150 \% 1$ & 200 & 300 & 500 & 497.94 & 99.59 \\
\hline 8 & $150 \% 2$ & 200 & 300 & 500 & 499.28 & 99.86 \\
\hline 9 & $150 \% 3$ & 200 & 300 & 500 & 498.23 & 99.64 \\
\hline \multicolumn{7}{|c|}{ Impurity 1} \\
\hline 1 & $50 \% 1$ & 2 & 1 & 3 & 3.01 & 100.33 \\
\hline 2 & $50 \% 2$ & 2 & 1 & 3 & 2.95 & 98.23 \\
\hline 3 & $50 \% 3$ & 2 & 1 & 3 & 2.98 & 99.22 \\
\hline 4 & $100 \% 1$ & 2 & 2 & 4 & 3.97 & 99.38 \\
\hline 5 & $100 \% 2$ & 2 & 2 & 4 & 4.04 & 101.07 \\
\hline 6 & $100 \% 3$ & 2 & 2 & 4 & 4.01 & 100.30 \\
\hline 7 & $150 \% 1$ & 2 & 3 & 5 & 5.04 & 100.76 \\
\hline 8 & $150 \% 2$ & 2 & 3 & 5 & 5.05 & 101.09 \\
\hline 9 & $150 \% 3$ & 2 & 3 & 5 & 5.01 & 100.29 \\
\hline
\end{tabular}

\section{Conclusion}

A RP-HPLC method to detect the EXDL drug along with its impurity 1 and 4 was successfully developed and found to be both accurate and reproducible. This chromatographic system easily separated two known impurities from the parent EXDL drug compound. The method was successfully separated the drug from its impurities with remarkable resolution. Validation results were found acceptable limits as per the guidelines. The method found sensitive in order to detect the impurities and précis, accurate and robust. The previous methods reported with EXDL drug were intended for formulation assay [11] and bio analytical [12] studies only. Hence there is no method reported for separation and identification of EXDL drug with impurities, the proposed RPHPLC method is a novel method. 
Table 8 Results of robustness

\begin{tabular}{|c|c|c|c|c|}
\hline \multirow[t]{2}{*}{ Method condition } & \multirow[t]{2}{*}{ System suitability conditions } & \multicolumn{3}{|c|}{ Results at robustness conditions } \\
\hline & & $\begin{array}{l}\text { Impurity } 4 \\
(2 \mu \mathrm{g} / \mathrm{mL})\end{array}$ & $\begin{array}{l}\text { Eluxadoline } \\
(200 \mu \mathrm{g} / \mathrm{mL})\end{array}$ & $\begin{array}{l}\text { Impurity } \\
1(2 \mu \mathrm{g} / \\
\mathrm{mL}\end{array}$ \\
\hline \multirow[t]{4}{*}{ Standard conditions } & Resolution & - & 6.55 & 3.21 \\
\hline & Tailing factor & 1.12 & 0.91 & 1.19 \\
\hline & Theoretical plates & 5418 & 14823 & 4195 \\
\hline & Retention time & 6.1167 & 9.3833 & 11.6500 \\
\hline \multirow[t]{4}{*}{ Detector wavelength: 249 nm } & Resolution & - & 6.55 & 3.39 \\
\hline & Tailing factor & 1.18 & 0.99 & 1.21 \\
\hline & Theoretical plates & 6100 & 14982 & 4132 \\
\hline & Retention time & 6.1323 & 9.3814 & 11.6142 \\
\hline \multirow[t]{4}{*}{ Detector wavelength: $247 \mathrm{~nm}$} & Resolution & - & 6.57 & 3.31 \\
\hline & Tailing factor & 1.11 & 0.98 & 1.22 \\
\hline & Theoretical plates & 5931 & 14824 & 4225 \\
\hline & Retention time & 6.1174 & 9.3816 & 11.6143 \\
\hline \multirow{4}{*}{$\begin{array}{l}\text { MP: Acetonitrile:Acetonitrile: } \\
\text { Methanol:0.1 M sodium } \\
\text { acetate 38:42:20 (v/v) }\end{array}$} & Resolution & - & 6.74 & 3.31 \\
\hline & Tailing factor & 1.11 & 0.98 & 1.22 \\
\hline & Theoretical plates & 5931 & 14824 & 4225 \\
\hline & Retention time & 6.1845 & 9.3743 & 11.6423 \\
\hline \multirow{4}{*}{$\begin{array}{l}\text { MP: Acetonitrile: Acetonitrile: } \\
\text { Methanol: 0.1 M sodium } \\
\text { acetate 42:38:20 (v/v) }\end{array}$} & Resolution & - & 6.88 & 3.82 \\
\hline & Tailing factor & 1.17 & 0.91 & 1.23 \\
\hline & Theoretical plates & 6125 & 14321 & 4182 \\
\hline & Retention time & 6.1375 & 9.3156 & 11.6075 \\
\hline \multirow[t]{4}{*}{ MP flow at $0.9 \mathrm{~mL} \min$} & Resolution & - & 6.94 & 3.47 \\
\hline & Tailing factor & 1.15 & 0.91 & 1.27 \\
\hline & Theoretical plates & 6528 & 14747 & 4195 \\
\hline & Retention time & 6.4167 & 9.6833 & 11.8167 \\
\hline \multirow[t]{4}{*}{ MP flow at $1.1 \mathrm{~mL} \min$} & Resolution & - & 6.91 & 3.45 \\
\hline & Tailing factor & 1.13 & 0.95 & 1.29 \\
\hline & Theoretical plates & 6326 & 14487 & 4262 \\
\hline & Retention time & 6.0167 & 9.1833 & 11.5167 \\
\hline
\end{tabular}


Table 9 Comparision of proposed method with existing method for EXDL

\begin{tabular}{|c|c|c|c|}
\hline \multirow[t]{2}{*}{ Parameter } & \multicolumn{3}{|c|}{ Results of method and validation parameters } \\
\hline & Proposed Method & Panigrahy et al. [9] & lqbal M et al. [10] \\
\hline Method & HPLC isocratic elution & HPLC isocratic elution & UPLC/MS \\
\hline Application & Impurity analysis & Bulk drug and dosage form analysis & Bio analytical \\
\hline Mobile phase & $\begin{array}{l}\text { Acetonitrile:methanol:0.1 M } \\
\text { sodium acetate 40:40:20 (v/v) }\end{array}$ & Acetonitrile:water 70:30 v/v & $\begin{array}{l}\text { Acetonitrile: } 20 \mathrm{mM} \text { ammo- } \\
\text { nium acetate }(80: 20, \mathrm{v} / \mathrm{v}) \\
\text { Oven temperature-fixed } \\
\text { to } 40^{\circ} \mathrm{C}\end{array}$ \\
\hline Linearity range & $\begin{array}{l}\text { Impurity } 4-1-6 \mu \mathrm{g} / \mathrm{mL} \\
\text { EXDL-10-600 } \mu \mathrm{g} / \mathrm{mL} \\
\text { Impurity } 1-1-6 \mu \mathrm{g} / \mathrm{mL}\end{array}$ & $10-125 \mu \mathrm{g} / \mathrm{mL}$ & $0.15-50 \mathrm{ng} \mathrm{mL}$ \\
\hline Retention time & $\begin{array}{l}\text { Impurity } 4-6.1167 \mathrm{~min} \\
\text { EXDL-9.433 } \min \\
\text { Impurity } 1-11.6333 \mathrm{~min}\end{array}$ & $3.481 \mathrm{~min}$ & $1.2 \mathrm{~min}$ \\
\hline LOD & $\begin{array}{l}\text { Impurity } 4-1 \mu \mathrm{g} / \mathrm{mL} \\
\text { EXDL-100 } \mu \mathrm{g} / \mathrm{mL} \\
\text { Impurity } 1-1 \mu \mathrm{g} / \mathrm{mL}\end{array}$ & $0.08 \mu \mathrm{g} / \mathrm{mL}$ & $0.07 \mathrm{ng} / \mathrm{mL}$ \\
\hline LOQ & $\begin{array}{l}\text { Impurity } 4-0.25 \mu \mathrm{g} / \mathrm{mL} \\
\text { EXDL-25 } \mu \mathrm{g} / \mathrm{mL} \\
\text { Impurity } 1-0.25 \mu \mathrm{g} / \mathrm{mL}\end{array}$ & $0.25 \mu \mathrm{g} / \mathrm{mL}$ & $0.15 \mathrm{ng} / \mathrm{mL}$ \\
\hline Advantage of the method & & $\begin{array}{l}\text { Application of impurity determination, wide } \\
\text { linearity range, sensitive impurity deterction }\end{array}$ & $\begin{array}{l}\text { Application of impurity } \\
\text { determination, simple } \\
\text { techniques than UPLC/ } \\
\text { MS, economic }\end{array}$ \\
\hline
\end{tabular}

Acknowledgements The authors wish to thank the management of GVK Biosciences Pvt. Ltd. for supporting this work.

Data availability All data generated analysed during this study are included in this published article.

\section{Compliance with ethical standards}

Conflict of interest The authors declare that they have no conflict of interest.

\section{References}

1. Breslin HJ, Diamond CJ, Kavash RW, Cai C, Dyatkin AB, Miskowski TA, Zhang SP, Wade PR, Hornby PJ, He W (2012) Identification of a dual delta OR antagonist/mu OR agonist as a potential therapeutic for diarrhea-predominant irritable bowel syndrome (IBSd). Bioorg Med Chem Lett 22(14):4869-4872

2. Garnock-Jones KP (2015) Eluxadoline: first global approval. Drugs 75(11):1305-1310

3. Dove LS, Lembo A, Randall CW, Fogel R, Andrae D, Davenport JM, McIntyre G, Almenoff JS, Covington PS (2013) Eluxadoline benefits patients with irritable bowel syndrome with diarrhea in a phase 2 study. Gastroenterology 145(2):329-38.e1

4. Davenport JM, Covington P, Bonifacio L, Mclntyre G, Venitz J (2015) Effect of uptake transporters OAT3 and OATP1B1 and efflux transporter MRP2 on the pharmacokinetics of eluxadoline. J Clin Pharmacol 55(5):534-542

5. Fujita W, Gomes I, Dove LS, Prohaska D, McIntyre G, Devi LA (2014) Molecular characterization of eluxadoline as a potential ligand targeting mu-delta opioid receptor heteromers. Biochem Pharmacol 92(3):448-456
6. Fragkos KC (2017) Spotlight on eluxadoline for the treatment of patients with irritable bowel syndrome with diarrhea. Clin Exp Gastroenterol 10:229-240

7. Levy-Cooperman N, McIntyre G, Bonifacio L, McDonnell M, Davenport JM, Covington PS, Dove LS, Sellers EM (2016) Abuse potential and pharmacodynamic characteristics of oral and intranasal eluxadoline, a mixed $\mu$ - and $\mathrm{k}$-opioid receptor agonist and $\delta$-opioid receptor antagonist. J Pharmacol Exp Ther 359(3):471-481

8. Lembo AJ, Lacy BE, Zuckerman MJ, Schey R, Dove LS, Andrae DA, Davenport JM, McIntyre G, Lopez R, Turner L, Covington PS (2016) Eluxadoline for irritable bowel syndrome with diarrhea. N Engl J Med 374(3):242-253

9. Panigrahy UP et al (2015) A novel validated RP-HPLC-DAD method for the estimation of eluxadoline in bulk and pharmaceutical dosage form. Res J Pharm Technol 8(11):1469-1476

10. Iqbal $M$ et al (2018) High throughput $\mu$-SPE based elution coupled with UPLC-MS/MS for determination of eluxadoline in plasma sample: application in pharmacokinetic characterization of PLGA nanoparticle formulations in rats. J Pharm Biomed Anal 5(149):172-178

11. Gazdag M (2000) 2.7 High performance liquid chromatography (HPLC) and related techniques. Progr Pharm Biomed Anal 4:210-239

12. Zaza S, Lucini SM, Sciascia F, Ferrone V, Cifelli R, Carlucci G, Locatelli M (2015) Recent advances in the separation and determination of impurities in pharmaceutical products. Instrum Sci Technol 43(2):182-196

13. ICH Topic Q 2 (R1) Validation of analytical procedures: text and methodology, $\mathrm{CPMP} / \mathrm{ICH} / 381 / 95$

14. ICH guideline, Impurities in new medicinal plants, CPMP/ $\mathrm{ICH} / 282 / 95$

Publisher's Note Springer Nature remains neutral with regard to jurisdictional claims in published maps and institutional affiliations. 